\title{
Using an Enhanced Dataset for Reassessing the Source Region of the 2003 Armería, Mexico Earthquake
}

\author{
Francisco J. NúÑez-Cornú, ${ }^{1}$ Marta Rutz-López, ${ }^{1}$ Víctor Márquez-Ramírez, ${ }^{2}$ \\ Carlos Suárez-Plascencia, ${ }^{1,2}$ and Elizabeth Trejo-Gómez ${ }^{1}$
}

\begin{abstract}
We present a fresh look at the source region of the 22 January $2003 M_{\mathrm{w}} 7.4$ Armería earthquake, which occurred off the Pacific coast of the state of Colima, Mexico, near the town of Armería. The effects of this earthquake in the neighboring states of Colima and Jalisco were different and stronger than those of previous recent major earthquakes in the region. This earthquake and its aftershocks were recorded by two local telemetered seismograph networks (RESCO and RESJAL). From 22 January to 24 January 2003, no important seismicity was located on the plates interface, or within the Rivera Plate, and most epicenters were located west of the Armería River, which is the western border of the Colima Graben, and is located outside of the Colima Gap region. From 24 January to 31 January, the seismicity recorded by both networks showed a migration in depth, with an almost vertical offshore distribution between 4 and $24 \mathrm{~km}$ in depth. For this period, a sevenstation portable digital seismograph network, equipped with threecomponent seismometers, was deployed in the epicentral area to study the aftershock sequence in detail. With this denser network more than $200 M_{\mathrm{L}}>2.0$ aftershocks were recorded. The aftershock foci were deeper than those recorded during the early period and most of them locate on a hypothetical $12^{\circ}$ dipping interface between the Rivera and North American Plates. Composite focal mechanism solutions for the aftershocks located during both periods indicate a reverse fault character that changes with time. Analysis of the new dataset still indicates that the earthquake was a shallow intraplate event.
\end{abstract}

Key words: Jalisco Block, Colima Graben, intraplate earthquake, aftershocks, subduction.

\section{Introduction}

On 22 January 2003 a shallow $M_{\mathrm{w}} 7.4$ earthquake $\left(18.6658^{\circ} \mathrm{W}, 104.0895^{\circ} \mathrm{N}\right.$, depth $\left.=5.0 \mathrm{~km}\right)$ occurred off the Pacific coast of the state of Colima, Mexico, near the town of Armería. This earthquake is the largest during the early twenty-first century in the area. Both the damage pattern and surface effects of this earthquake in the neighboring states of Colima and Jalisco were stronger than those caused by recent large earthquakes in these regions and affected different areas; especially in Colima City and Zapotitlan de Vadillo, Jalisco, on the western flank of the Colima volcano. This earthquake and its aftershocks were recorded by two local telemetered seismograph networks: The Red Sísmica Telemétrica de Colima (RESCO) and the Red Sísmica Digital Telemétrica de Jalisco (RESJAL). Additionally, to have detailed data of the aftershock sequence, a portable digital seismograph network (PN) was deployed from 24 to 31 January 2003. The PN recorded more than $200 \mathrm{M}_{\mathrm{L}}>2.0$ earthquakes. In this paper we present the results of the analysis of the newly gathered dataset, and compare them with the results reported for the initial $72 \mathrm{~h}$ of seismicity (NúÑEZ-CoRnú et al., 2004).

\section{Historical Seismicity and Previous Studies}

The largest $(M=8.2)$ earthquake of the twenti-

1 Centro de Sismología y Volcanología de Occidente, Universidad de Guadalajara, 48280 Puerto Vallarta, JAL, Mexico. Email: pacornu77@gmail.com

2 Posgrado en Ciencias de la Tierra, Centro de Investigación Científica y Educación Superior de Ensenada, Ensenada, B.C., Mexico. eth century in Mexico occurred in 1932 in the Jalisco Block (JB) region (Fig. 1), a tectonically complex, seismically active zone. This earthquake was followed 15 days later by another large event $(M=7.8)$. Singh et al. (1985) studied this sequence 


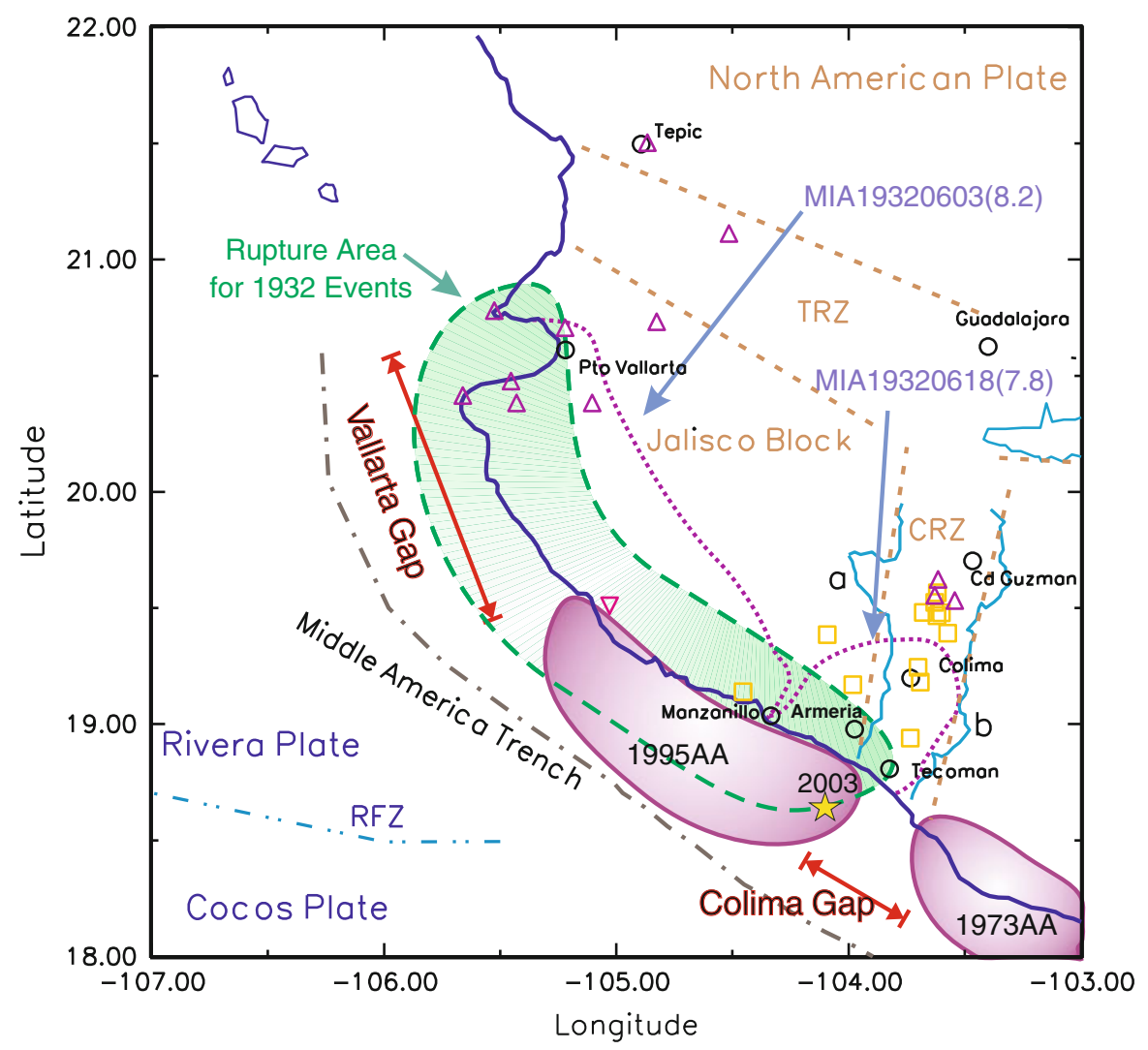

Figure 1

Map of a portion of western Mexico showing the seismotectonic features of the Jalisco region. RFZ Rivera Fault Zone, CRZ Colima Rift Zone, TRZ Tepic-Zacoalco Rift Zone, $a$ Armería River, $b$ Cohuayana River, MIA maximum intensity areas for earthquakes in 1932 (dates and magnitudes indicated), $A A$ aftershocks areas. Seismograph stations are marked with squares (RESCO network), triangles (RESJAL network), and inverted triangle (CJIG station of the SSN). Circles cities. Solid star epicenter of the Armería earthquake (NúNEZ-CoRNú et al., 2004)

and concluded that the composite rupture area straddles the entire coast of the states of Jalisco and Colima, they also suggested a recurrence time of 77 years for major earthquakes in this region. In 1995 a $M_{\mathrm{w}}=8.0$ earthquake (E95) near Manzanillo involved part of the 1932 rupture area but left unruptured patches to the north and south, termed the Vallarta and Colima gaps, respectively (Fig. 1). In spite of the occurrence of large earthquakes and the associated high seismic hazard in the region, only one permanent broadband seismograph station at Chamela [station CJIG, from the Mexican Seismograph Network (SSN)] and a short-period, analog-telemetry network (RESCO) were operating on the Colima Rift Zone to monitor seismicity in the area until 2001 (Fig. 1). In late 2001, a new seismograph network, RESJAL, began to be deployed by the Jalisco Civil Defense and the Centro de Sismología y Volcanología de Occidente, SisVOc (NúÑEZ-CoRnú et al., 2001). Currently, this network features 11 stations (six of them telemetered); all equipped with three component-1 Hz sensors (LE3D type) and 24-bit data loggers (Fig. 1). From studies of microearthquakes in the JB during 1996-1998, NúÑEZ-CoRnú et al. (2002) found that the subduction of the Rivera Plate under the North American Plate exhibits a double seismic zone, with a subduction angle smaller than $15^{\circ}$ up to $160 \mathrm{~km}$ from the trench; and identified various seismogenic zones, showing that data from the SSN alone are not enough to accurately determine the seismic patterns in the JB region. The seismicity recorded throughout 2002 by RESJAL and RESCO confirmed these results (NÚÑEZ-CORNÚ et al., 2003). 


\section{Tectonic Setting}

The North American, Pacific, Cocos, and Rivera lithospheric plates interact in western Mexico (Fig. 1), yet the seismotectonic setting is poorly understood. A tectonic unit known as the Jalisco Block has been proposed in this region (LuHR et al., 1985; Burgois et al., 1988). The Jalisco Block is limited to the east by the Colima Rift Zone (CRZ) and to the north by the Tepic-Zacoalco Rift Zone (TRZ). There is general agreement that the Jalisco Block is actively separating from the continent, moving in a WNW direction away from mainland Mexico (BuRgois et al., 1988; Garduño and Tibaldi, 1991; Allan et al., 1991), although alternative models have also been proposed (FerRari et al., 1994; Rosas-Elguera et al., 1996).

To date, the geometry of Rivera Plate under the JB is also unclear. Eissler and McNally (1984) and SingH et al. (1985) suggested a dip angle of $20^{\circ}$ for the interface between the Rivera and North American Plates. NúÑEZ-CoRnú and SÁNCHEZ-MorA (1999), reported a dip angle of $12^{\circ}$ as estimated from local seismicity data, and similar values were obtained from reflection-refraction studies carried out in the central and northern regions of the Jalisco coast (DAÑobeitia et al., 1997). More controversial are the geometry of the interface and the relative motion between the Rivera and Cocos Plates. Does the interface lie under the CRZ (NIXON, 1982) or further north (EISSLER and McNALLY, 1984)? Is it a convergent (DeMets and Stein, 1990) or divergent (BANDY, 1992) boundary? The CRZ, which is roughly delimited at surface by the Armería and Cohuayana rivers (Figs. 1, 2), has been related to this boundary (BANDY, 1992; FERRARI et al., 1994; BANDY et al., 1995), or alternatively, to a spreading center location (LuHR et al., 1985). More recently GRAND et al. (2007) reported on results from teleseismic tomography that indicates a tear between the subducting Rivera and Cocos Plates along a trend that is at west of the CRZ, consistent with the proposal of BANDY et al. (1995). Thus, it is not clear what underlies the CRZ: a contact zone between the subducted Rivera and Cocos Plates, a tear zone, or a spreading center.

\section{Data and Results}

During the first 3 days following the mainshock (22-24 January, Period I) a group of 72 aftershocks recorded by RESJAL and RESCO were processed for accurate locations. For details of the analysis of this initial dataset the reader is referred to NúÑEZ-CoRNú et al. (2004). Here we present the analysis of the aftershocks recorded during 24-31 January (Period II) and compare it with that of Period I. Also for this period, SisVOc and RESCO, with the support of Colima Civil Defense, deployed a portable network (PN) with seven digital 3D seismographs to study the aftershocks; an analysis of these data is presented and compared with results from RESJAL and RESCO data.

For period II, 40 aftershocks could be located using RESJAL and RESCO data, employing the same criteria as for Period I. Figure $2 \mathrm{a}$ and $\mathrm{b}$ show maps of epicenters located during Period I and Period II, respectively. We observe that during Period II seismicity persisted in the area of the Armería cluster (AC), beneath the epicentral area of the mainshock of 22 January with a different depth distribution, while it almost disappeared from the 95 earthquake cluster (95C) (NúÑEZ-CoRnú et al., 2004). Figure 2c and d show the depth distribution, along a profile perpendicular to the trench; here we observe the change in depth distribution for the period II, Many of the aftershocks are deeper than during period I, and are vertically distributed 3 and $24 \mathrm{~km}$ depth. In Fig. 2e and $\mathrm{f}$ we present the distribution of these aftershocks along a profile parallel to the trench, we observe clearly that most of the seismicity is consistent with the $\mathrm{AC}$ cluster and shows an almost vertical distribution.

An analysis of the frequency-magnitude distribution (FMD) for periods I and II results in $b=0.66$, which is consistent with average values estimated for crustal seismicity (Frolich and DAVIS, 1993), the magnitude threshold for this data is 3.0 (Fig. 3).

With the deployed portable stations the detection capabilities were enhanced, and 200 aftershocks with magnitude $\geq 2.0$ were located during Period II (this magnitude threshold allows us to include readings from RESCO and nearby RESJAL stations), the 

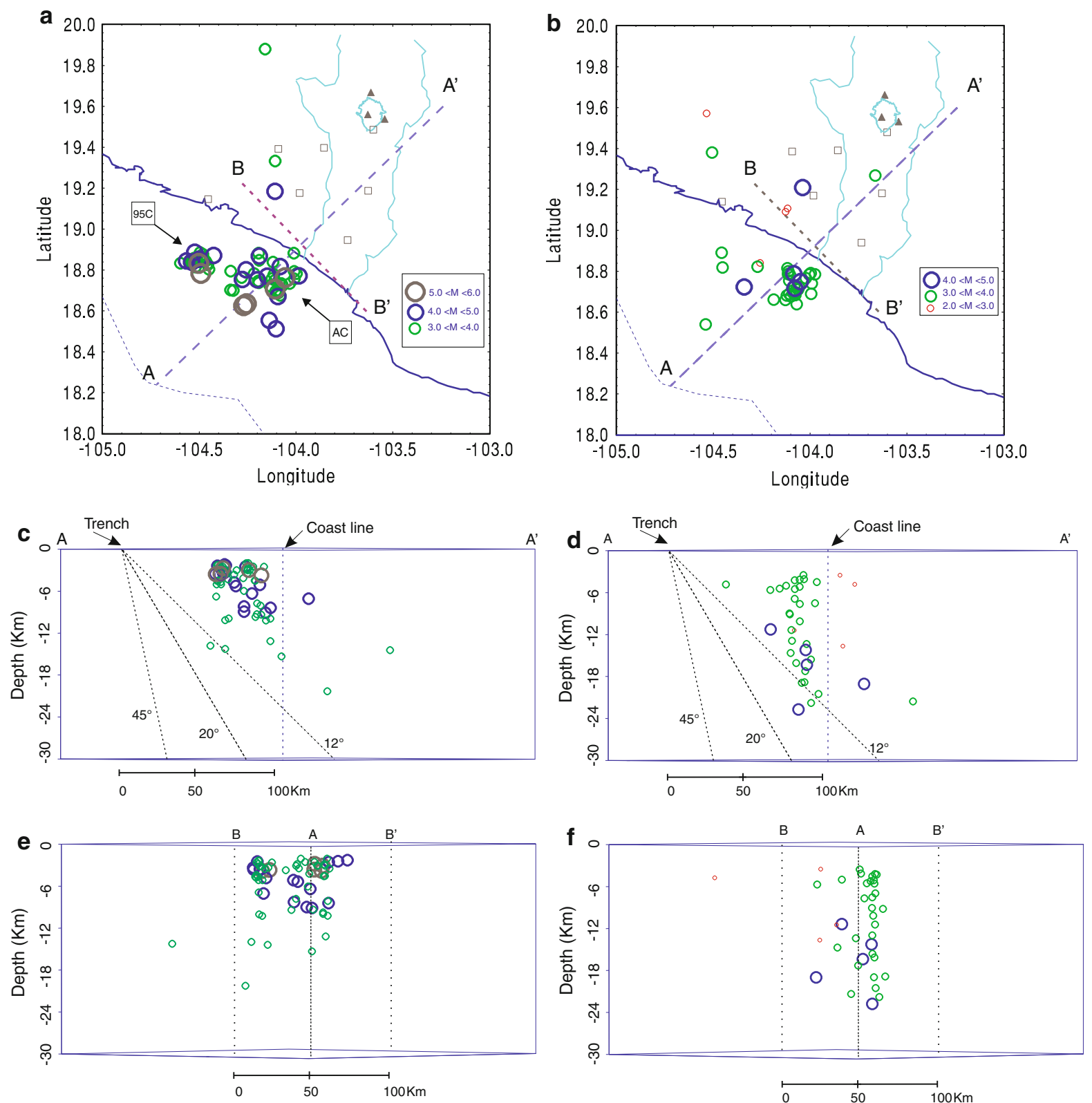

Figure 2

Locations of earthquakes recorded from 24 January to January 31 using different sets of data. Top row map views, center row profile perpendicular to the trench $\left(A-A^{\prime}\right)$, bottom row profile parallel to the trench $\left(B-B^{\prime}\right)$. Circles mark earthquakes locations. Dashed line outline of the Middle America trench. Solid thin gray lines Armería and Cohuayana rivers. a, c, e Locations obtained using arrival phase data from RESCO and RESJAL stations as in NúÑEZ-CoRNú et al. (2004). b, d, f locations obtained using arrival phase data from RESCO and RESJAL stations for Period II (June 24-31). Open squares RESCO stations, solid triangles RESJAL stations. AC Armería cluster; $95 C$ Earthquake 1995 cluster

velocity model used is the one proposed in NúÑEZCoRnú et al. (2004). To estimate the quality of the hypocentral locations, we show the aftershocks located with data from the RESCO and RESJAL networks (Fig. 2b, d, f) and the results with data from the PN, RESCO and RESJAL networks (Fig. 4a-c) using the same residual criteria (NúÑEZ-CORNú et al., 2004). No significant differences are observed in the 


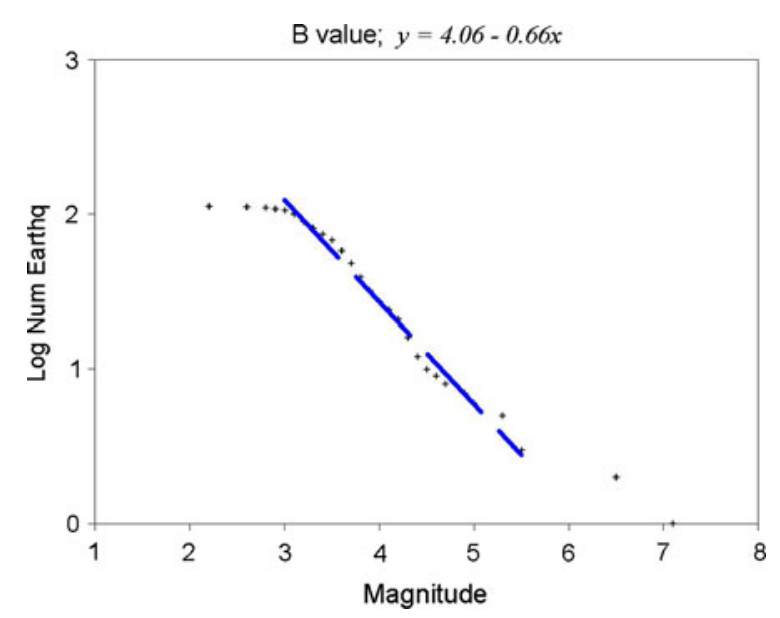

Figure 3

Frequency-magnitude distribution (FMD) for aftershocks recorded during periods I and II using RESJAL and RESCO data

epicentral distribution (Figs. 2b, 4a). However, the inclusion of the local stations shows a difference in the depth distribution which is observed among Fig. $4 \mathrm{~b}$ and c, the depth range in Fig. $4 \mathrm{~b}$ and $\mathrm{c}$ is between 6 and $21 \mathrm{~km}$, instead of 3-24 km in Fig. $2 \mathrm{~d}$ and $\mathrm{f}$, we see that shallower events are $3-5 \mathrm{~km}$ deeper. Two hypocenter clusters can be observed, a shallower one between 6 and $10 \mathrm{~km}$ depth which corresponds to the zone of the AC cluster of the first $72 \mathrm{~h}$ aftershocks and a second, deeper one which locates between 12 and $21 \mathrm{~km}$ depth, along a hypothetical slab interface dipping $12^{\circ}$. The vertical alignment observed in Fig. $2 \mathrm{c}$ is also observed in Fig. 4c.

Figure 5a shows the epicentral distribution of the 200 aftershocks located with the portable array data, which is, in general, similar to Fig. 4a. In Fig. 5b, which shows a section perpendicular to the trench, we observe a hypocenter group that agrees with the AC cluster, a second larger group of the hypocenters locates between 12 and $21 \mathrm{~km}$ depth, along a hypothetical slab interface dipping $12^{\circ}$, another group locates roughly between 21 and $31 \mathrm{~km}$ depth with an almost vertical distribution that appears to be inside the slab, or perhaps delineating the slab tip. The hypocentral distribution in Fig. $5 \mathrm{c}$ is roughly the same that Fig. 4c.

To gain insight into the source properties of the Armería seismic sequence, we compute composite focal mechanism solutions using the computer
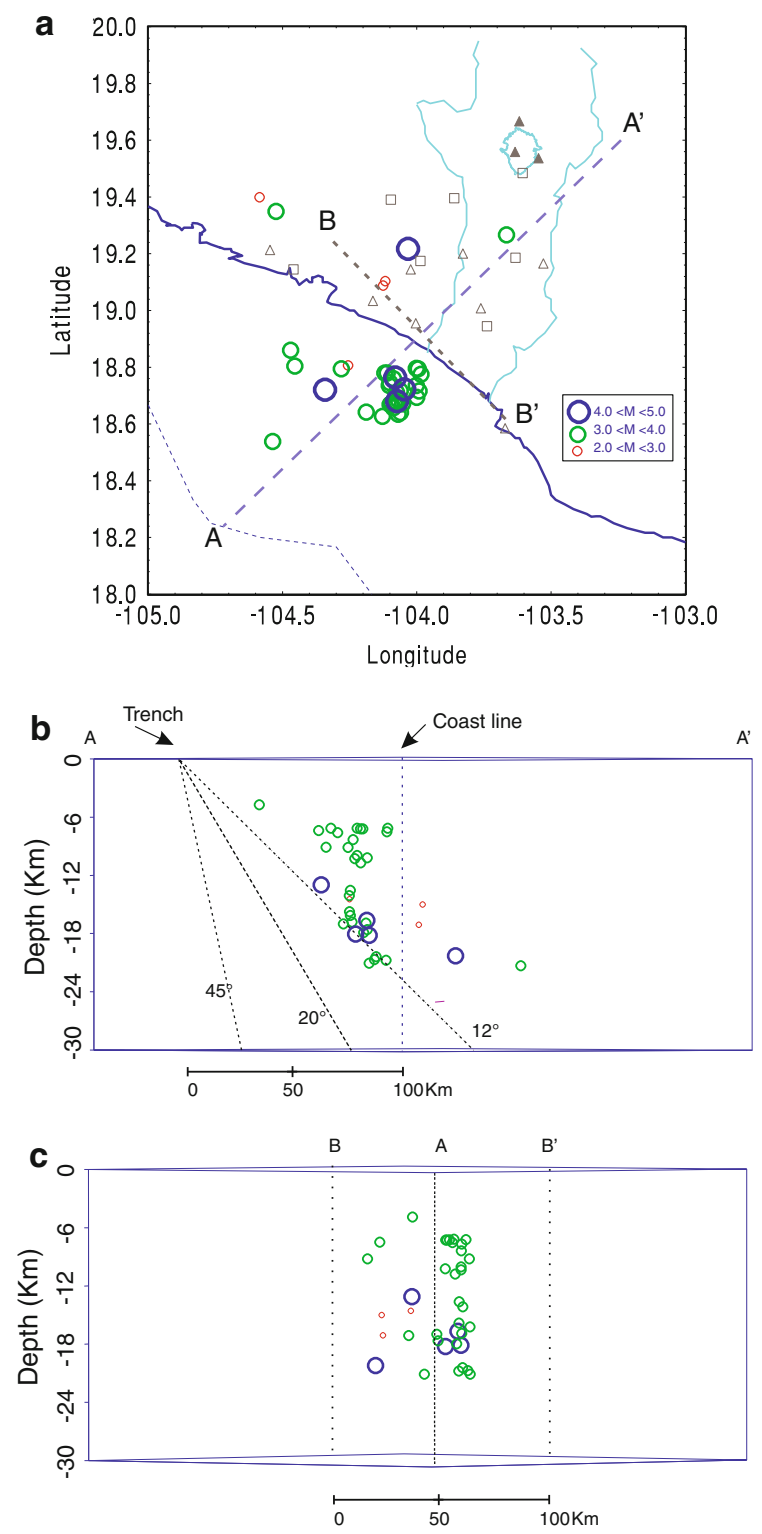

Figure 4

Locations of the same aftershocks in Fig. 2b, d, f, including Portable Network data. a Epicentral distribution. b Profile perpendicular to the trench $\left(A-A^{\prime}\right)$. c Profile parallel to the trench $\left(B-B^{\prime}\right)$. Open squares RESCO stations, solid triangles RESJAL stations, open triangles temporal network

program MEC93, a modified version of the computer program MECSTA (UDíAs et al., 1982), which use polarities of first arrivals and is based on the probabilistic algorithm proposed by BRILLINGER et al. (1980), we use the output data (azimuth and takeoff angle) from HYPO71 (LEE and LAHR, 1975). From a total of 272 events 115 were selected and grouped by 

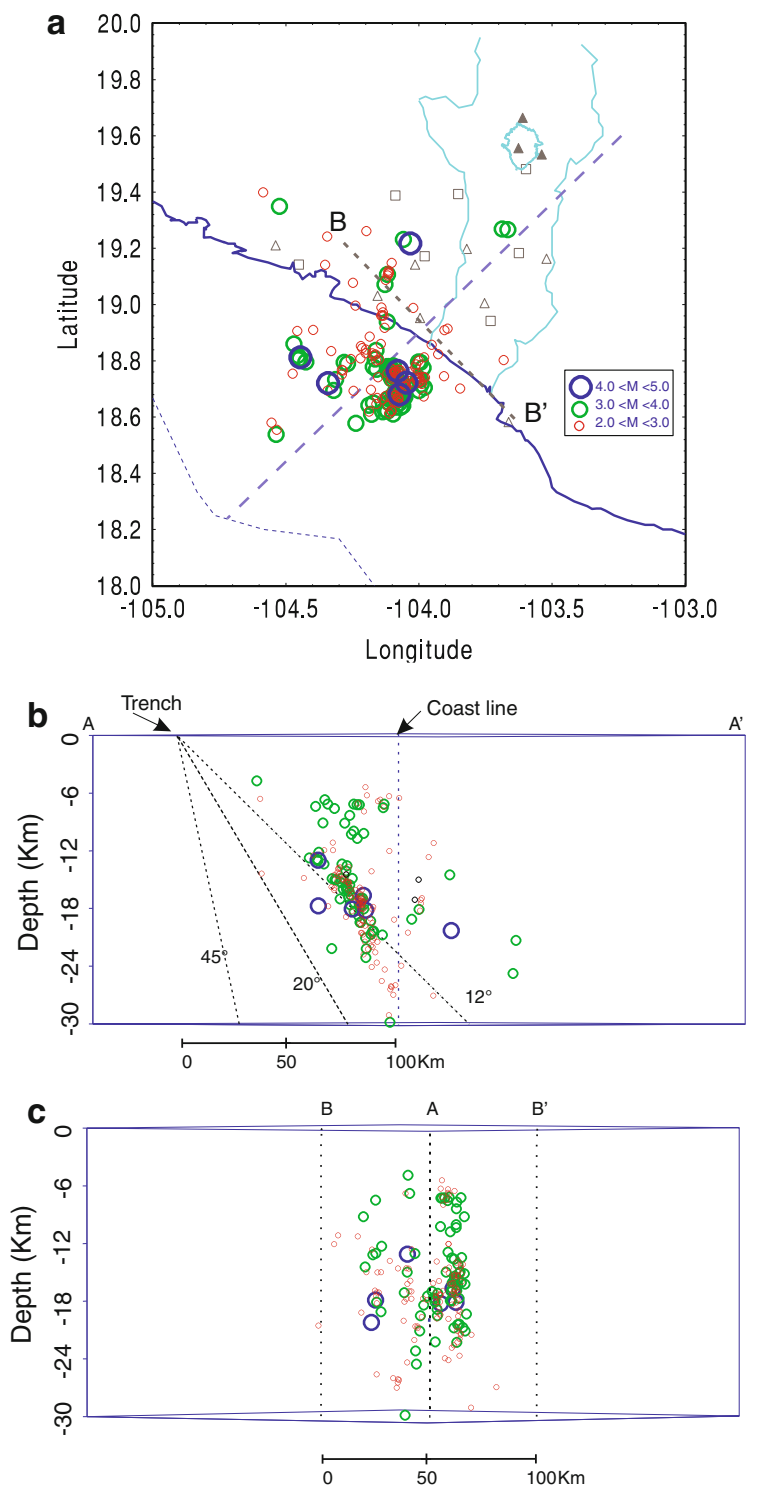

Figure 5

Aftershocks located using portable network seismic data for period 24-31 January a epicentral distribution. b Profile perpendicular to the trench $\left(A-A^{\prime}\right)$. c Profile parallel to the trench $\left(B-B^{\prime}\right)$. Open squares RESCO stations, solid triangles RESJAL stations, open triangles temporal network

the program into four solutions (Fig. 6): Group 1 composed of 25 earthquakes, Group 2 composed of 46 earthquakes (this solution is similar to one reported for the two principal aftershocks by NúÑEZCornú et al., 2004), Group 3 composed of 35 earthquakes (this solution is similar to one reported for the Main Event by NúÑEZ-CoRnú et al., 2004), and these groups are consistent with reverse fault solutions. The fourth group with nine earthquakes is consistent with a normal fault solution.

The spatio-temporal distribution of aftershocks according to their focal mechanisms is shown in Fig. $7 \mathrm{a}-\mathrm{c}$, although no clear spatial pattern is observable (Fig. 7a, b), a possible variation with time of the composite reverse focal mechanism solutions is apparent from Fig. 7c. From this figure it is possible to observe that aftershocks of Group 1 took place between 22 January and 26 January; aftershocks of Group 2 between 26 January and 29 January and the events included in Group 3 between January 29 and January 31. Meanwhile shocks of Group 4 occurred sparsely from 22 January to 31 January.

\section{Discussion and Conclusions}

In a previous work (NúÑEZ-CORNú et al., 2004) it was found that during the early days (22-24 January) following the $M_{\mathrm{w}} 7.4$ Armería mainshock, no important seismicity was located on the hypothetical interface between the Rivera and North American Plates that could support the suggestion of the Armería shock being a subduction earthquake breaking the Colima Gap. In this study, using the data from RESCO and RESJAL, one can observe a migration in depth of the aftershocks after $72 \mathrm{~h}$.

The same conditions of station coverage and location procedure for the earthquakes in Period I were applied to a set of earthquakes recorded during the Period II. We found that the hypocentral distribution is different from one period to another with earthquakes during Period II locating at deeper levels within the crust and being aligned almost vertically, reaching the plate interface [assuming a dip of $12^{\circ}$ ] (Fig. 2d, f). The inclusion of the data from the PN stations improves the quality of the hypocentral depth of the locations; however, the location of AC cluster remains almost at the same depth. This fact supports that the main event was an intraplate continental earthquake.

We also used an expanded dataset to analyze the aftershock activity from 22 January to 31 January 2003, and found that: (1) Most of the aftershock activity $(M<3.0)$ is located on the plate interface (assuming a dip of $12^{\circ}$ ), and possibly delineates the 


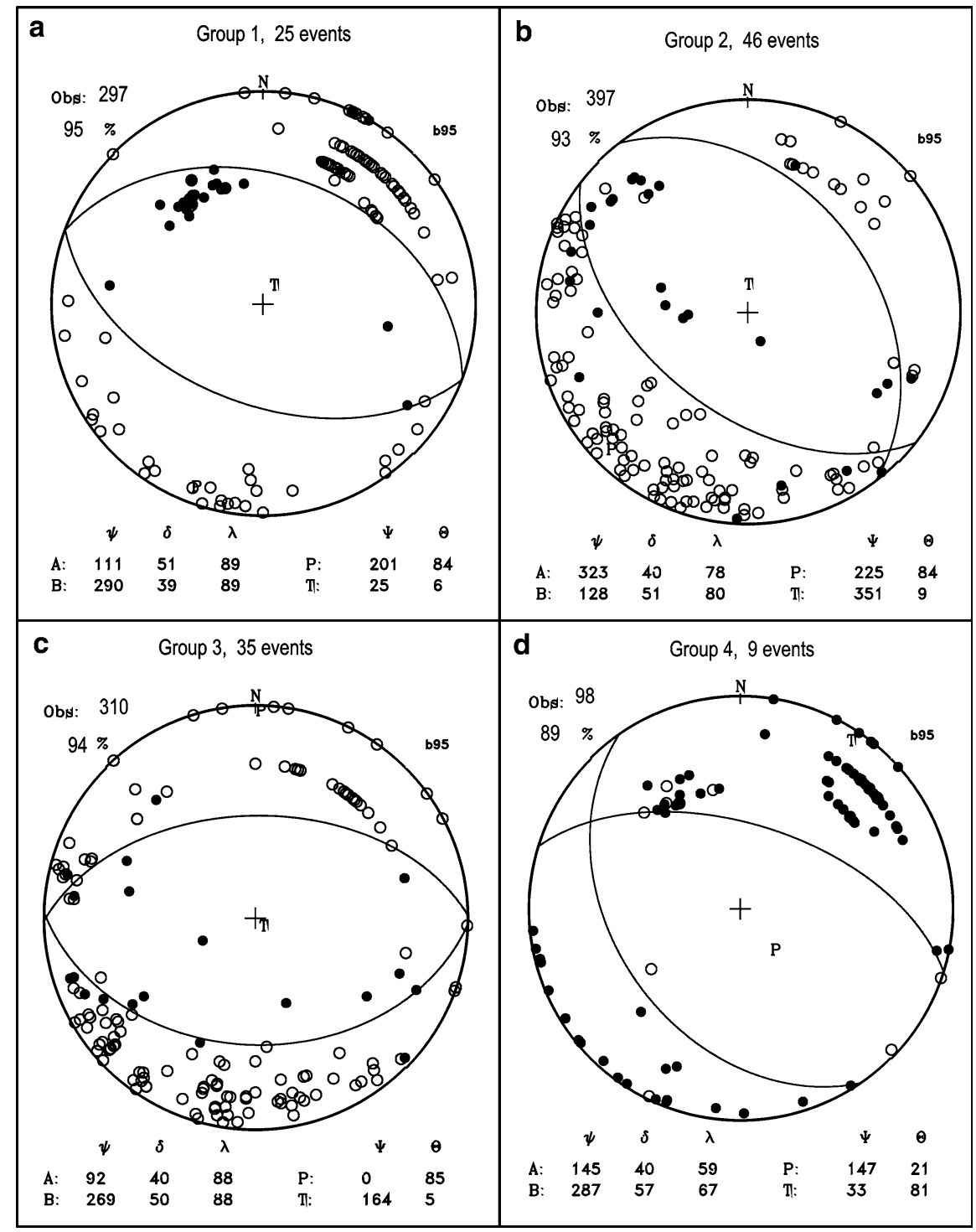

Figure 6

Focal mechanism composite solutions for aftershocks groups. a Group 1: earthquakes from 22 January to 26 January, b Group 2: earthquakes from 26 January to 29 January, c Group 3: earthquakes from 29 January to 31 January, and d Group 4: earthquakes from 22 January to 31 January. The group and the number of earthquakes used to compute each solution are indicated above the plots. Lower hemisphere projections are used. Solid black circles compressions, hollow circles dilatations. $T$ tension axis, $P$ pressure axis. $A$ and $B$ labels beneath each solution indicate the two planes and their orientations in degrees ( $\psi$ strike, $\delta$ dip, $\lambda$ rake, $\Psi$ azimuth, $\Theta$ plunge). Obs number of first motion polarities used. Percentages indicate values of $p$ scores, which measure the fit of a set of observations with respect to the joint solution (BRILLINGER et al.,

tip of the slab, or a fault in it; (2) the vertical aftershock alignment observed in Figs. 2f, $4 \mathrm{c}$ and $5 \mathrm{c}$ suggests a feature coinciding with the mouth of Armeria River, that could be related with the western border of Colima Graben; (3) the composite focal mechanisms for temporarily grouped subsets of earthquakes are mostly consistent with steeply dipping reverse faulting; and (4) there is an difference in the orientation of faulting as evidenced by the rotated fault plane solution for Group 3. This difference could indicate that the rupture at shallower levels during the mainshock and early aftershocks 

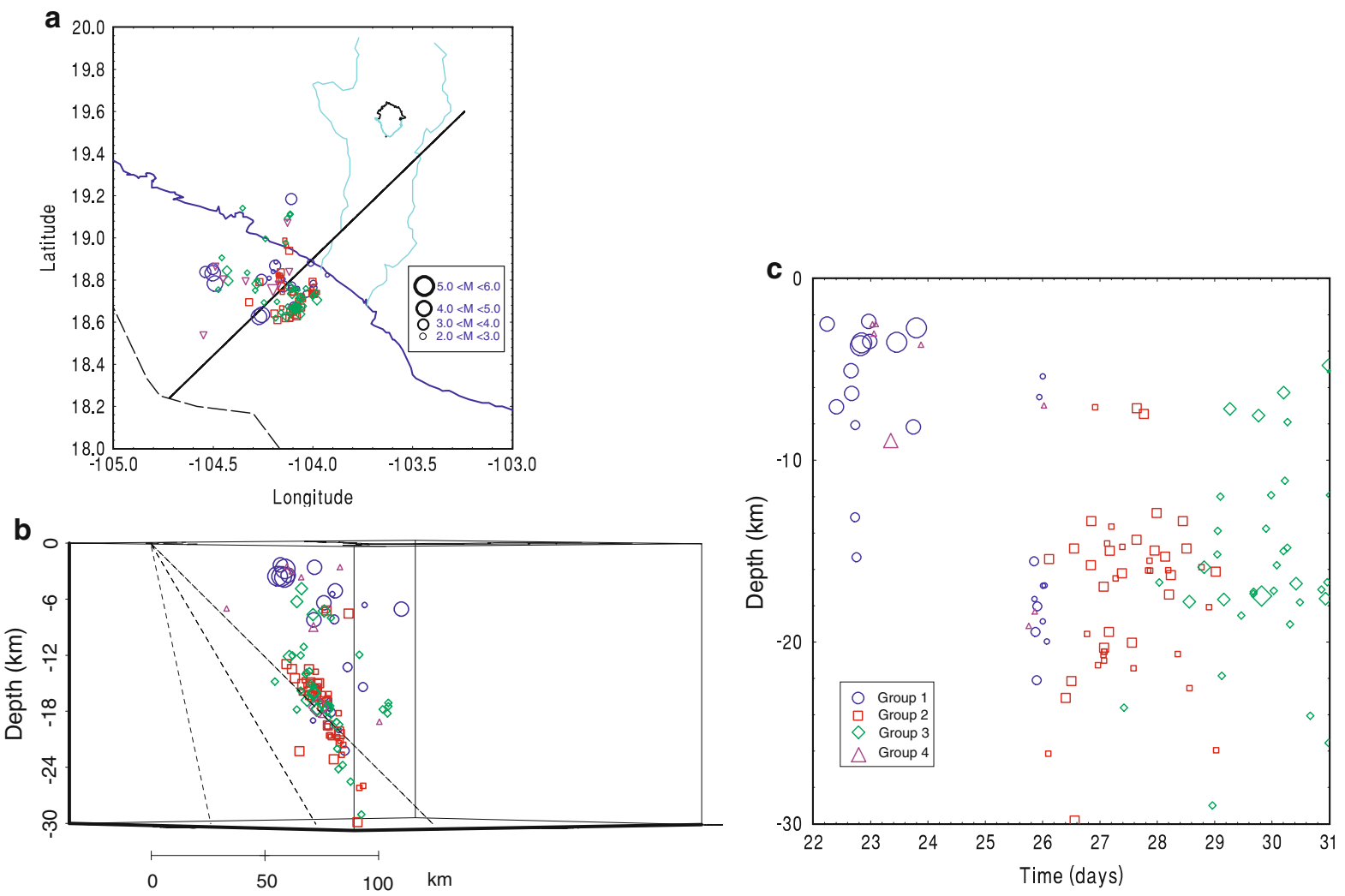

Figure 7

Spatial distribution for hypocenters of aftershocks according to their similar focal mechanism solutions. Circles Group 1, squares Group 2, diamonds Group 3, triangles Group 4. Sizes of symbols are proportional to magnitudes. a Epicentral distribution, b distribution along a profile perpendicular to the trench. $\mathbf{c}$ Temporal against depth distribution of aftershocks. Conventions as in a

proceeded, and possibly contributed to, faulting at deeper levels which may have reached the plate interface and penetrated into the subducted Rivera Plate.

The composite fault plane solutions computed for groups of aftershocks indicate mostly reverse faulting on likely steep planes (dipping between $39^{\circ}$ and $51^{\circ}$ ) and oriented NW-SE or roughly E-W. Given that no surface rupture, cracks, or liquefaction could be documented in the epicentral area during the mainshock, we cannot ascertain the precise orientation of the associated fault. The apparent switch in orientation and location of faulting with time (Fig. 7c) could indicate highly heterogeneous conditions in the upper $20 \mathrm{~km}$ of the crust in the region surrounding the epicentral area of the Armería earthquake, as well as short-term temporal variability of frictional resistance and stress loading on the faults (Deichmann and García-FernandeZ, 1992).
The results presented here indicate that the 2003 Armería earthquake occurred on a continental intraplate reverse fault, in contrast to other works that favor faulting along the subduction interface between the Rivera and North American Plates (YAGi et al., 2004; Singh et al., 2003). We suggest that the Armería shock and its aftershocks could represent partial accommodation of deformation in the continental crust caused by oblique subduction.

The 2003 Armería, Mexico earthquake is the largest earthquake in the Jalisco region during the last 14 years, and the damage pattern was quite different to the damage due to the 1995 Earthquake. This earthquake has been the focus of attention because there is the open question as to what it could represent in terms of the seismotectonics of the region and the associated seismic hazard. In this work we show results from an extended dataset with accurate location of aftershocks (recorded during the first 9 days 
following the mainshock), and fault plane modeling from local $\mathrm{P}$ wave arrivals and find that the observations are consistent with a rupture along a steeply dipping plane that locates mainly above any projection of a subducting interface within a wide range of dip angles. We suggest that the Armería earthquake represents slip on a fault in the continental crust. Our observations do not support rupture of the Colima Gap, but point to disruption of a region within the 1995 earthquake rupture zone. This has implications for seismic hazard because the Armería earthquake could have caused stress changes and possibly loading of a region within the largely unaffected Colima Gap. This is a matter for future research. We note that the epicentral region of the 2003 Armería earthquake shows activity that is consistent with shallow crustal seismicity. No triggered seismicity effects were reported by RESCO and RESJAL outside the epicentral region, including the active Colima Volcano.

\section{Acknowledgments}

The authors wish to thank comments and revisions by anonymous reviewers which greatly improved the manuscript. Support from Congreso del Estado de Jalisco (C. Dip. Jesus García) for field work is acknowledged. Digital Seismograms used in this study were collected as part of joint projects of University of Guadalajara and PCJal. Additional RESCO data was kindly provided by G. ReyesDavila.

Open Access This article is distributed under the terms of the Creative Commons Attribution Noncommercial License which permits any noncommercial use, distribution, and reproduction in any medium, provided the original author(s) and source are credited.

\section{REFERENCES}

Allan, J. F., Nelson, J., Luhr, J., Carmichael, J., Wopat, M., and WALLACE P., Pliocene-Holocene rifting and associated volcanism in southwest Mexico: An exotic terrain in the making. In The Gulf and Peninsular Provinces of the Californias, vol 47, (ed. J. P. Dauphin and R. R. T. Simoneit) (American Association Petroleum Geologists, Tulsa, Oklahoma, 425-445, 1991).

BANDY, W. L. (1992), Geological and geophysical investigation of the Rivera-Cocos Plate boundary: implications for plate fragmentation, Ph.D. Thesis, Texas A\&M University, College Station, Texas.

Bandy, W. L., Mortera-Gutierrez, C., Urrutia-Fucugauchi, J., and HiLde, T. W. C. (1995), The subducted Rivera-Cocos plate boundary: Where is it, what is it, and what is its relationship to the Colima rift? Geophys. Res. Lett. 22, 3075-3078.

Brillinger, D., UdíAs, A., and Bolt, B. (1980), A probability model for regional focal mechanism solutions, Bull. Seism. Soc. Am. 70, 1121-1133.

Bourgois J., Renard, D., Auboin, J., Bandy, W., Barrier, E., Calmus, T., Carfantan, J. C., Guerrero, J., Mammerickx, J., Mercier De Lepinay, B., Michaud, F., and Sosson, R. (1988). Fragmentation en cours du bord continental nord américain: les frontières sous marines du bloc de Jalisco (Mexique). Campagne Seamat du N/O Jean Charcot, Juin-Juillet 1987, C. R. Acad. Sci. Paris 307(II), 1121-1130.

Dañobeitia, J. J., Cordoba, D., Delgado-Argote, L. A., Michaud, F., Bartolomé, R., Farran, M., NúÑez-Cornú, F., and CarboNELL, R. (1997), Expedition gathers new data on crust beneath Mexican west coast, EOS Trans. AGU 78, 565.

Deichmann, N. and García-Fernandez, M. (1992), Rupture geometry from high-precision relative hypocenter locations of microearthquake clusters, Geophys. J. Int. 110, 501-517.

DeMets, C. and Stein, S. (1990), Present-day kinematics of the Rivera plate and implications for tectonics in southwestern Mexico, J. Geophys. Res. 95, 21931-21948.

EIssler H. and McNally, K. C. (1984), Seismicity and tectonics of the Rivera Plate and implications for the 1932 Jalisco, Mexico, earthquake, J. Geophys. Res. 89, 4520-4530.

Ferrari, L., Pasquaré, G., Venegas, S., Castillo, D., and Romero, F. (1994). Regional tectonics of western Mexico and its implications for the northern boundary of Jalisco Block. Geofís Inter 33, 139-151.

Frolich, C. and Davis, S. (1993), Teleseismic b-values: or much ado about 1.0, J. Geophys. Res. 98, 631-634.

Garduño V. H. and Tibaldi, A. (1991), Kinematic evolution of the continental active triple junction of the western Mexican Volcanic Belt, C. R. Acad. Sci. Paris 307, 135-142.

Grand, S. P., Yang, T., Wilson, D., Guzmán Speziale, M., Gómez GonzÁlez, J., DomínguEZ-Reyes, T., and NI, J. (2007), Seismic structure of the Rivera subduction zone, EOS Trans. AGU 88 (Fall Meet. Suppl.), abstract T41C-0702.

LEE, W. H. K and LAHR, J. C. (1975), HYPO71 (revised): a computer program for determining hypocenter, magnitude, and first motion pattern of local earthquakes, U.S. Geol. Surv. Open-File Rept. 75-311, 59 pp.

Luhr, J., Nelson, S., Allan, J., and Carmichael, I. (1985), Active rifting in southwestern Mexico: Manifestations of an incipient eastward spreading-ridge jump, Geology 13, 54-57.

NIxON, G. T. (1982), The relationship between Quaternary volcanism in central Mexico and the seismicity and structure of subducted ocean lithosphere, Geol. Soc. Am. Bull. 98, 514-523.

NúÑEz-Cornú, F. J. and SÁnChEZ-Mora, C. (1999), Stress field estimations for Colima Volcano, Mexico based on Seismic data, Bull. Volc. 60, 568-580.

Núñez-Cornú, F., Reyes-Dávila, G., Suárez-Plascencia, C., GonzÁlez-Ledezma, M., and García-Puga, J. (2001), The Jalisco Seismic Telemetric Network, EOS Trans. AGU 82, F821.

NúÑez-Cornú, F. J., Rutz, M., Nava, F. A., Reyes-Davila, G., and Suárez-Plascencia, C. (2002), Characteristics of Seismicity in 
the Coast and North of Jalisco Block, Mexico, Phys. Earth Planet. Int. 132, 141-155.

NúÑez-Cornú, F. J., Rutz, M., Suárez-Plascencia, C., ReyesDÁvila, G., and Nava, F. A. (2003), Seismotectonics of Jalisco Block, Mexico, Conference proceedings of The Geological Society of America annual meeting, Cordilleran Section, 35(4), 71-72.

NúÑez-Cornú, F. J., Reyes-Dávila, G. A., Rutz, M., Trejo-Gómez, E., Camarena-García, M. A., and Ramírez-Vazquez, C. A. (2004), The 2003 Armería, Mexico earthquake (Mw 7.4): Mainshock and early aftershocks, Seism. Res. Lett. 75, 734-743.

Rosas-Elguera, J., Ferrari, L., Garduño-Monroy, V., and Urrutia-Fucugauchi, J. (1996), Continental boundaries of the Jalisco Block in the Pliocene-Quaternary kinematics of western Mexico, Geology, 24, 921-924.
Singh, S. K., Ponce, L., and Ninshenko, S. P. (1985), The great Jalisco, Mexico earthquakes of 1932: Subduction of the Rivera plate, Bull. Seism. Soc. Am. 75, 1301-1313.

Singh, S. K., Pacheco, J. F., Alcántara, L., Reyes, G., Ordáz, M., Iglesias, A., Alcocer, S. M., Gutiérrez, C., Valdés, C., and Kostoglodov, V. (2003), A preliminary report on the Tecomán, Mexico earthquake of 22 January 2003 (Mw 7.4) and its effects, Seism. Res. Lett. 74(3), 279-289.

Udías, A., Bufforn, E., Brillinger, D., and Bolt, B. (1982), Joint statistical determination of fault-plane parameters, Phys. Earth Planet. Int. 30, 178-184.

Yagi, Y., Mikumo, T., Pacheco, J., and Reyes, G. (2004), Source Rupture Process of the Tecoman, Colima, Mexico Earthquake of 22 January 2003, determinated by Joint Inversion of Teleseismic Body-Wave and Near Source Data, Bull. Seism. Soc. Am. 94(5), 1795-1807.

(Received January 6, 2010, revised June 16, 2010, accepted June 25, 2010, Published online July 30, 2010) 